\title{
POTENSI EKOWISATA PANTAI MOLOTABU KABUPATEN BONE BOLANGO BERDASARKAN ANALISIS SPASIAL EKOLOGIS \\ The Potential of Molotabu Beach Ecotourism, Bone Bolango Regency Based on Ecological Spatial Analysis
}

\author{
Sunarty Suly Eraku${ }^{1}$, Mohamad Karmin Baruadi² ${ }^{2}$ Aang Panji Permana ${ }^{3}$, Hendra $^{1}$, Nurdin \\ Mohamad $^{1}$
}

\footnotetext{
${ }^{1}$ Prodi Pendidikan Geografi, Fakultas Matematika dan IPA, Universitas Negeri Gorontalo, Indonesia ${ }^{2}$ Prodi Bahasa dan Sastra Indonesia, Fakultas Sastra dan Budaya, Universitas Negeri Gorontalo, Indonesia ${ }^{3}$ Prodi Teknik Geologi, Fakultas Matematika dan IPA, Universitas Negeri Gorontalo, Indonesia Email Korespondensi: aang@ung.ac.id
}

DOI: $10.31314 /$ jsig.v3i2.668

Abstract - The development of the coastal area in Bone Bolango Regency is a huge potential for ecotourism. Ecotourism development focuses on aspects of nature conservation, aspects of socio-cultural and economic empowerment of local communities, aspects of learning and education. One of the ecotourism potentials of coastal areas in Bone Bolango Regency is the Molotabu beach area. The purpose of this research is to analyze the potential of the Molotabu beach ecotourism area based on the physical parameters of the socio-cultural, economic and institutional parameters. To achieve this purpose, an ecological spatial approach is used using the Geographical Information System. Field observation research methods consisted of direct measurements, interviews, and questionnaires. The research analysis used quantitatively, namely descriptive statistical analysis, scoring analysis and qualitative descriptive analysis for the final assessment of the potential of Molotabu beach ecotourism. Based on the results of the analysis of the physical parameters of the beach, namely vegetation, environmental cleanliness, beach material and water transparency, Molotabu beach has high potential. The same results were also obtained for the measurement of physical parameters including distance, infrastructure, accessibility and attractiveness of the Molotabu beach ecotourism area. High potential for ecotourism is also obtained from criteria based on institutional, socio-cultural, economic and environmental parameters. The high potential of Molotabu Beach ecotourism is because this coastal area has the potential for natural scenery, underwater beauty, crafts, regional arts and culinary.

Keywords: Ecotourism, Geographical Information System, Molotabu Beach

\begin{abstract}
Abstrak - Pengembangan kawasan pantai di Kabupaten Bone Bolango menjadi potensi ekowisata sangat besar. Pengembangan ekowisata menitikberatkan pada aspek konservasi alam, aspek pemberdayaan sosial budaya ekonomi masyarakat lokal, aspek pembelajaran dan pendidikan. Salah satu potensi ekowisata daerah pantai di Kabupaten Bone Bolango adalah Kawasan pantai Molotabu. Tujuan penelitian ini menganalisis potensi kawasan ekowisata pantai Molotabu berdasarkan parameter fisik parameter sosial budaya, ekonomi dan kelembagaan. Untuk mencapai tujuan tersebut maka digunakan pendekatan secara spasial ekologis dengan menggunakan Sistem Informasi Geografis. Metode penelitian observasi lapangan terdiri dari pengukuran langsung, wawancara, dan penyebaran kuesioner. Analisis penelitian yang digunakan secara kuantitatif yakni analisis statistik deskriptif, analisis skoring dan analisis deskriptif kualitatif untuk penilaian akhir potensi ekowisata pantai Molotabu. Berdasarkan hasil analisis parameter fisik pantai yakni vegetasi, kebersihan lingkungan, material pantai dan kecerahanan air pantai Molotabu memiliki potensi tinggi. Hasil yang sama juga diperoleh untuk pengukuran parameter fisik meliputi jarak, sarana prasarana aksesibilitas dan daya tarik kawasan ekowisata pantai Molotabu. Potensi tinggi ekowisata diperoleh juga dari kriteria berdasarkan parameter kelembagaan, sosial budaya, ekonomi dan lingkungan. Tingginya potensi ekowisata Pantai Molotabu karena kawasan pantai ini memiliki potensi pemandangan alam, keindahan bawah laut, kerajinan, kesenian daerah dan kuliner.
\end{abstract}

Kata kunci: Ekowisata, Sistem Informasi Geografis, Pantai Molotabu 


\section{PENDAHULUAN}

Kabupaten Bone Bolango yang terletak di sebelah timur Provinsi Gorontalo memiliki potensi pariwisata. Potensi pariwisatanya sangat beragam mulai dari wisata alam (ecotourism), wisata budaya hingga wisata bahari. Keragaman potensi tersebut merupakan modal yang besar dalam pengembangan daya tarik wisata terhadap peningkatan pendapatan asli daerah (PAD). Keragaman potensi tersebut merupakan kekayaan sumber daya alam dan budaya yang dapat dikembangkan. Namun pengembangan potensi kekayaan alam dan budaya tersebut baru sebagian kecil yang dikelola sebagai daya tarik wisata (Kementerian Pariwisata dan Ekonomi Kreatif, 2020). Potensi wisata Provinsi Gorontalo didukung juga kondisi morfologi maupun kondisi geologi seperti potensi sumber daya alam, penyebaran batugamping dan struktur geologi (Permana dan Eraku, 2017; Eraku et al., 2017; Permana, 2018; Permana et al., 2019a, Permana et al., 2019b; Eraku dan Permana, 2020; Permana et al., 2020).

Wilayah pesisir kabupaten Bone Bolango memiliki potensi besar dalam pengembangan pariwisata sebagai kawasan ekowisata. Karena, menurut Peraturan Menteri Dalam Negeri No 33 Tahun 2009, kegiatan wisata alam diharapkan menjadi upaya konservasi sumber daya alam namun tetap memperhatikan sektor pendidikan dan peningkatan pendapatan masyarakat lokal. Selain itu, menyatukan konservasi, komunitas, dan pengembangan yang berkelanjutan menjadi target utama (Ghorbani et al., 2015). Hal yang menarik dan prostisius untuk dibahas dalam perencanaan dan strategi pengembangan industri ekowisata (Motlagh et al., 2020). Ekowisata merupakan bentuk wisata paling berharga dari pengembangan pariwisata berkelanjutan (Haryanto, 2014; Motlagh et al., 2020). Ekowisata merupakan salah satu kunci dalam pengembangan kawasan obyek pariwisata. Karena ekowisata memiliki manfaat dalam hal sosial, ekonomi, lingkungan, pemanfaatan sumber daya alam, dan berdampak langsung pada masyarakat setempat (Zambrano et al., 2010; Nyaupane dan Poudel, 2011; Liu et al., 2014).

Pantai Molotabu merupakan kawasan yang sangat berpotensi sebagai lokasi ekowisata bagi penduduk Kota Gorontalo dan sekitarnya. Pantai ini mempunyai pemandangan dengan bentangan alam luas (bukit dan laut) serta memiliki garis pantai yang panjang dan luas disepanjang pesisir serta air laut yang tenang. Pantai Molotabu juga merupakan lokasi terbaik menikmati pesona sunrise dan sunset yang indah sehingga kawasan Pantai Molotabu sangat berpotensi untuk dikembangkan menjadi ekowisata. Peran serta masyarakat menjadi penting dalam pengelolaan ekowisata ini mengingat dalam pemanfaatan keindahan alam dan budaya serta sejarah harus dijaga kelestariannya demi kesejahteraan masyarakat (WWF, 2009).

Peningkatan sarana dan prasarana atau fasilitas menjadi faktor penting dalam pengembangan potensi wisata sehingga peran serta masyarakat juga dilibatkan secara menyeluruh dan berkelanjutan (Kementerian Pariwisata dan Ekonomi Kreatif, 2020). Pariwisata berbasis masyarakat akan meningkatkan pendapatan kesadaran masyarakat lokal tentang pelestarian alam diantaranya mengelola limbah dari kegiatan pariwisata sehingga mendorong wisatawan untuk tinggal lebih lama (Vitasurya, 2015; Qian et al., 2016). Selain itu, ekowisata harus memperhatikan kearifan lokal menjadi landasan pembangunan pariwisata berkelanjutan yang tentunya didukung oleh partisipasi masyarakat dalam mengembangkan infrastruktur dan sarana pendukungnya sendiri (Vitasurya, 2015)

Konsep pengembangan wisata Pantai Molotabu ini diselaraskan dengan isu-isu konservasi lingkungan dan pemberdayaan masyarakat lokal sehingga menjadi suatu kawasan ekowisata. Keunikan dan keindahan kawasan ini akan dipetakan dalam penelitian ini untuk pengembangan kawasan ekowisata Pantai Molotabu. Oleh karena itu perlu dilakukan riset tentang analisis potensi ekowisata di kawasan Pantai Molotabu. Tujuan penelitian ini menganalisis potensi kawasan ekowisata Pantai Molotabu berdasarkan parameter fisik parameter sosial budaya, ekonomi dan kelembagaan.

\section{METODE DAN DATA}

Pendekatan yang digunakan secara spasial ekologis dengan menggunakan Sistem Informasi Geografis (SIG). Metode penelitian yang digunakan terdiri dari dua metode yakni pengumpulan data dan analisis. Untuk metode pengumpulan data terdiri dari data primer dan sekunder. Data primer dikumpulkan lewat observasi (pengukuran langsung di lapangan), wawancara, dan kuesioner. Sedangkan data sekunder dikumpulkan lewat pustaka dan dokumen dari instansi terkait. Analisis yang digunakan ada dua yaknni analisis kuantitatif dan kualitatif. 

1671

Analisis kuantitatif terdiri dari analisis statistik deskriptif (hasil kuesioner), analisis skoring (parameter fisik) sedangkan analisis kualitatif (deskriptif) digunakan pada penilaian akhir potensi ekowisata Pantai Molotabu.

\section{Pengumpulan Data}

Nilai potensi suatu obyek ekowisata ditentukan mengacu parameter fisik yakni mengalikan nilai masing-masing parameter dengan bobot suatu parameter. Kemudian hasil yang didapat selanjutnya dijumlahkan berdasarkan nilai-nilai parameter fisik obyek yang terdiri dari jarak, sarana prasarana aksesibilitas dan daya tarik. Untuk kriteria penilaian potensi ekowisata alam dan budaya berdasarkan parameter kelembagaan, sosial budaya, ekonomi dan lingkungan. penentuan nilai skoring pada parameter PKSEL sama dengan penentuan nilai skoring pada parameter Parameter Fisik (PF). Dimana masing-msing parameter kelembagaan, sosial, budaya dan lingkungan (PKSEL) dikalikan dengan bobot parameter. Hasilnya selanjutnya dijumlahkan berdasarkan nilai-nilai parameter KSEL menggunakan rumus skoring.

\section{Data Analisis}

Analisis data untuk mendapatkan nilai potensi ekowisata yaitu dengan mencari mean dari hasil total nilai skor obyek wisata yang dijumlahkan. Penilaian dibagi menjadi dua yakni PF dan PKSEL. Nilai skor potensi yang diperoleh, kemudian dimasukan kedalam klasifikasi penilaian dengan interval kelas kesesuaian ditentukan dengan rumusan menurut (Walpole, 1982).

\section{HASIL DAN PEMBAHASAN}

\section{Kondisi Geografis Pantai Molotabu}

Desa Molotabu merupakan salah satu wilayah pesisir di Kabupaten Bone Bolango yang memiliki potensi wisata pantai. Desa Molotabu termasuk pada desa administratif Pemerintahan Kecamatan Kabila Bone Kabupaten Bone Bolango. Berdasarkan data potensi desa, luas wilayah Desa Molotabu adalah $\pm 1.173,10$ ha. Desa Molotabu terletak di areal perbukitan dan pegunungan bagian utara Kabupaten Bone Bolango. Batas utara Desa Molotabu yakni Kecamatan Suwawa, batas selatan adalah Teluk Tomini, batas timur yakni Kecamatan Bone Pantai dan batas barat dengan Kecamatan Botupingge. Morfologi desa ini yang terluas terdiri dari pegunungan dan dataran rendah. Desa Molotabu terdiri dari empat dusun yaitu Dusun Tanjung Karang, Molotabu Barat, Molotabu Tengah dan Waolo. Peta kawasan ekowisata Pantai Molotabu di Kabupaten Bone Bolango ditunjukkan pada Gambar 1.

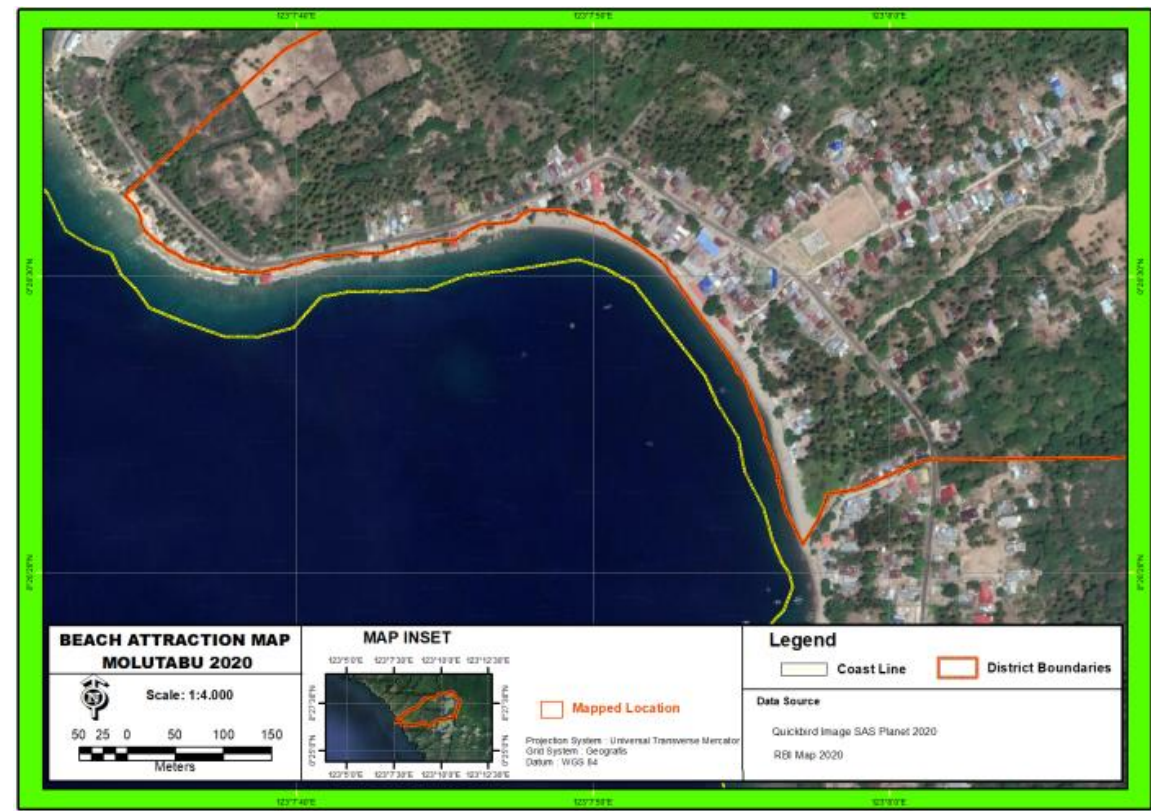

Gambar 1. Peta Kawasan Ekowisata Pantai Molotabu Kabupaten Bone Bolango (Sumber : Quickbird Image SAS Planet, 2020) 

1671

\section{Analisis Kawasan Ekowisata Pantai Molotabu}

Kawasan ekowisata Pantai Molotabu ditumbuhi berbagai macam vegetasi seperti pohon kelapa dan pohon besar yang tumbuh disekitar pinggi pantai. Vegetasi pada kawasan ini masih sangat terjaga dengan baik. Material pantai di kawasan ekowisata pantai Molotabu terdapat kandungan pasir halus, kerikil, dan batu sedang diakibatkan oleh gelombang dan angin sehingga pecahan batuan-batuan karang yang kecil serta material halus akan dibawa oleh air laut ke pinggir pantai. Nilai kecerahan air di Pantai Molotabu sangat cocok masuk kategori rekreasi seperti aktivitas berenang di pantai. Kebersihan lingkungan kawasan ekowisata pantai Molotabu masih terjaga dengan baik. Masyarakat sudah paham kebersihan lingkungan merupakan suatu hal yang harus dijaga pada setiap objek wisata. Berdasarkan hasil analisis parameter fisik pantai yakni vegetasi, kebersihan lingkungan, material pantai dan kecerahanan air Pantai Molotabu memiliki potensi tinggi untuk dikembangkan. Kawasan ekowisata Pantai Molotabu di Kabupaten Bone Bolango ditunjukkan pada Gambar 2.

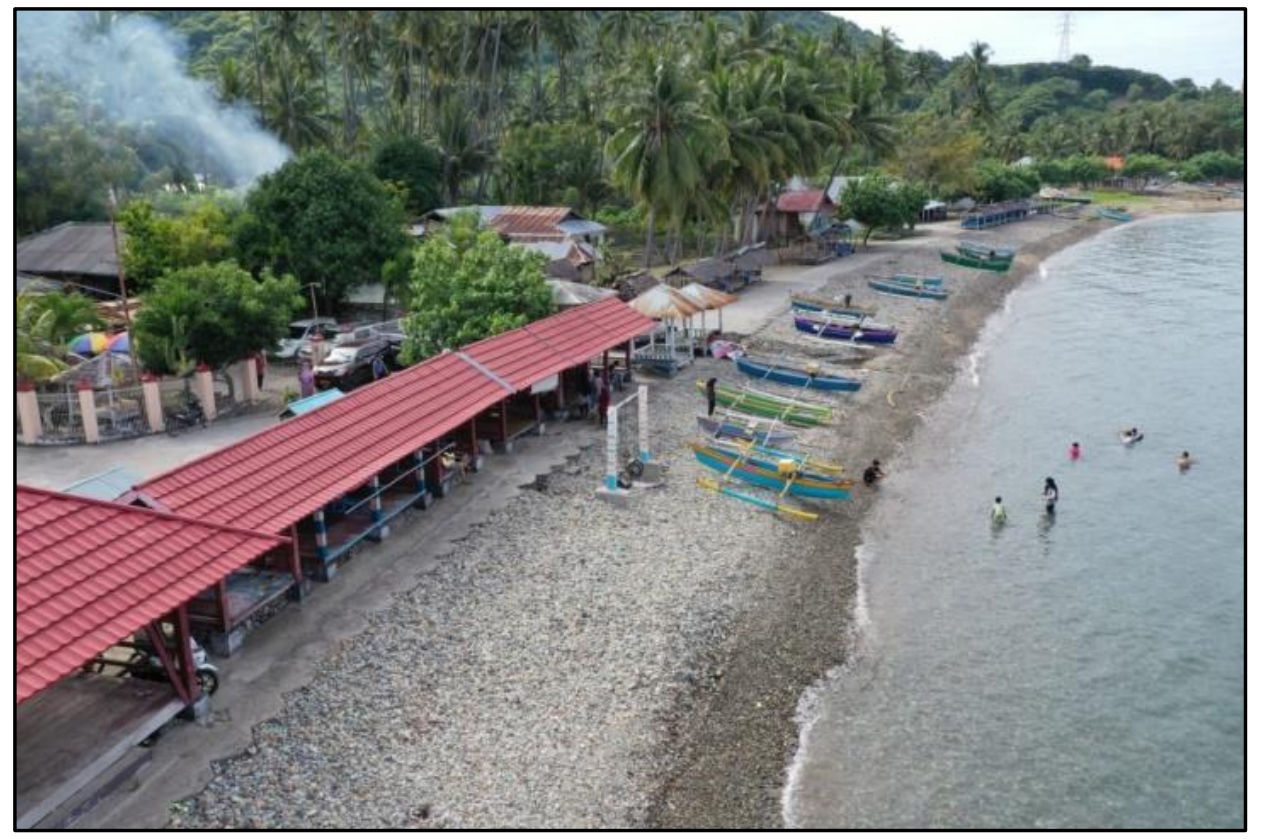

Gambar 2. Kawasan Pantai Molotabu Berupa Kawasan Pantai yang memanjang

Pantai Molotabu berjarak 24,5836 km dari pusat ibukota Kabupaten Bone Bolango yang jika ditempuh dengan kendaraan bermotor baik roda dua maupun roda empat memakan waktu 30 menit. Pengukuran jarak dilakukan dengan mengukur panjang jalan dari masing-masing lokasi ibukota kabupaten/kota ke suatu lokasi objek wisata di masing-masing kabupaten/kota. Proses pengukuran ini dilakukan dengan menggunakan tools jalur terpendek yang terdapat dalam software Quantum Gis. Dalam menggunakan tools ini beberapa parameter yang dibutuhkan untuk mengukur jarak adalah titik koordinat asal dan tujuan yaitu diukur dari koordinat pusat ibu kota kabupaten ke titik koordinat objek wisata. Aksesibilitas menuju Pantai Molotabu juga cukup baik karena didukung dengan jalan aspal yang baik. Kawasan ekowisata pantai Molotabu mulai dikelola oleh masyarakat sebagai tempat wisata sejak masyarakat bekerjasama untuk membangun beberapa gazebo sebagai tempat untuk para wisatawan yang datang. Setelah itu pemerintah kabupaten Bone Bolango merenovasi gazebo dan mengganti atap rumbia dengan atap seng. Sarana dan prasarana yang tersedia di Pantai Molotabu dalam radius $1 \mathrm{~km}$ adalah penginapan, rumah ibadah, fasilitas kesehatan yang berupa puskesmas. Selain itu fasilitas yang dapat dinikmati didalamnya adalah berupa ban pelampung untuk bermain air, perahu sewa, serta tempat berteduh berupa gazebo.

Penilaian objek wisata mengacu daya tarik lewat cara membuat buffer sebesar $1 \mathrm{~km}$ pada masing-masing objek wisata dan dilakukan identifikasi jenis suatu objek wisata yang berada pada area/poligon buffer tersebut. Berdasarkan hasil penilaian potensial wisata Pantai Molotabu memiliki kategori tinggi dikarenakan banyaknya kegiatan ekowisata yakni berenang, snorkeling, 

1671

memancing, berperahu dengan banana boat dan kegiatan lainnya. Salah satunya bisa menikmati sunrise dan sunset di pinggir pantai. Keberadaan dan ketersediaan air bersih di kawasan ini menjadi hal penting karena untuk membilas, mandi cuci dan kakus. Hasil penilaian kawasan ini sudah diidentifikasi memiliki sumber air bersih yang berada pada radius $1 \mathrm{~km}$ dengan lokasi objek sehingga sangat mendukung untuk pengembangan ekowisata pantai.

Wisatawan yang datang ke Pantai Molotabu pada umumnya wisatawan lokal. Era new normal saat ini berdampak pada banyaknya wisatawan dari Kabupaten Bone Bolango, Kota dan Kabupaten Gorontalo yang mengunjungi tempat ini. Wisatawan tersebut datang secara berkelompok, baik dalam bentuk keluarga, rombongan sekolah, institusi pemerintah/ swasta, dan kelompok anak muda. Oleh karena itu masyarakat Molotabu membuat pengumuman untuk tetap menjaga protokol kesehatan. Kreativitas dari pemuda kelompok sadar wisata Molotabu membuat pengumuman wisata sehat di era new normal dalam bahasa Gorontalo. Pengumuman protokol kesehatan ditunjukkan pada Gambar 3.

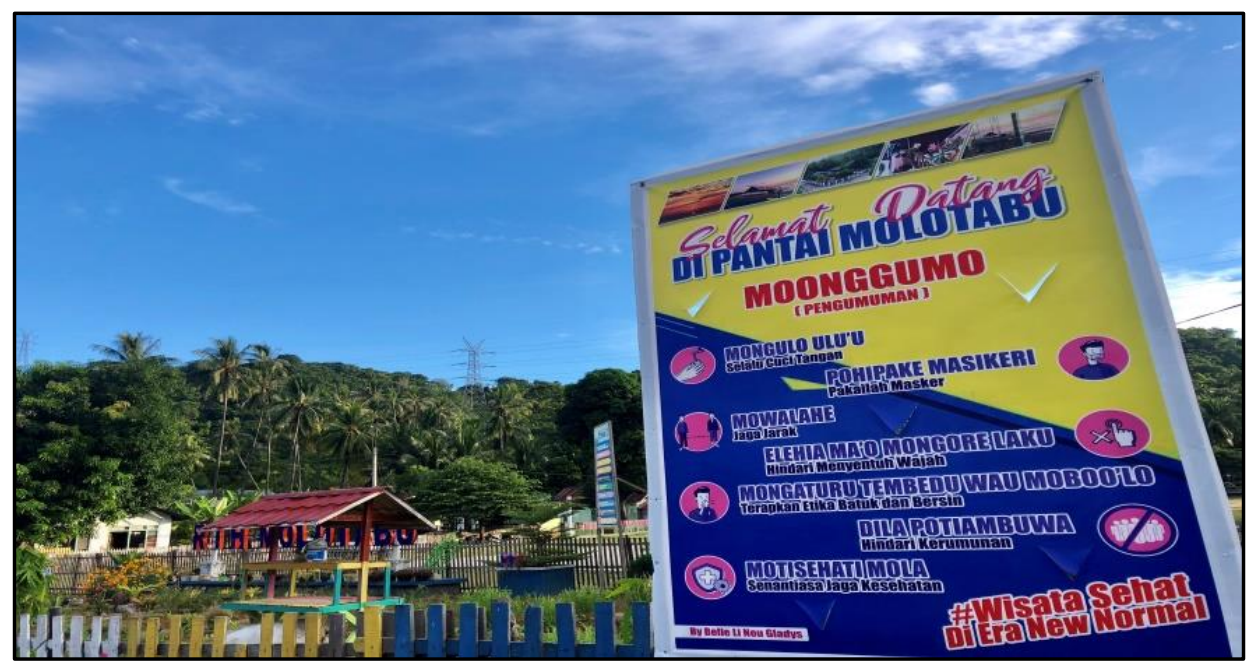

Gambar 3. Papan Pengumuman untuk Wisata Sehat di Era New Normal

Penilaian potensi mengacu parameter kelembagaan, sosial budaya, ekonomi dan lingkungan menunjukkan hasil yang sangat mendukung. Hal ini dikarenakan perkembangan objek wisata ini terjadi secara alamiah karena peran serta masyarakat secara swadaya dengan membuat bangunan-bangunan berupa fasilitas tempat untuk bersantai yang disewakan atau dijadikan tempat usaha yang menunjang kegiatan wisata. Oleh karena itu, pengelolaannya cenderung dilakukan oleh masyarakat secara kolektif. Pantai Molotabu berada di bawah tanggung jawab Dinas Pariwisata dan Ekonomi Kreatif Bone Bolango. Keterlibatan masyarakat di kawasan Pantai Molotabu dalam pengembangan ekowisata terlihat jelas yakni menjadi pengelola, pedagang kuliner, menyiapkan lahan parkir, penyewaan gazebo dan membuka usaha penginapan. Selain kekayaan ekowisata pantai alami ternyata wisatawan dapat menikmati kehidupan nelayan yang unik dan tradisional. Kehidupan atau aktivitas nelayan terdiri dari pencarian ikan, pelelangan dan wisata kuliner dari hasil laut sehingga menjadi daya tarik tersendiri bagi wisatawan saat berkunjung di Pantai Molotabu. Pengembangan ekowisata Pantai Molotabu melibatkan seluruh masyarakat Desa Molotabu sehingga berdampak positif bagi masyarakat secara langsung.

Berdasarkan nilai skoring akhir dari hasil penjumlahan nilai parameter fisik dan parameter kelembagaan sosial, ekonomi, dan lingkungan kemudian dibagi dua, kawasan ekowisata Pantai Molotabu memiliki potensi tinggi. Karena pemanfaatan keindahan alam yang utuh, kekhasan budaya dan sejarah oleh masyarakat. Adanya potensi pemandangan alam, menikmati sunrise dan sunset yang sangat indah (Gambar 4), keindahan laut untuk kegiatan snorkeling dan diving. Selain itu, ada kerajinan, kesenian daerah, peringatan hari Asyura, wisata budaya dan kuliner. Pengembangan Pantai Molotabu memberikan keuntungan secara ekonomi sekaligus meningkatkan pendapatan masyarakat. 
Eraku, S. S., dkk., 2020 Jurnal Sains Informasi Geografi [J SIG], 3(2):100-107, ISSN 26141671

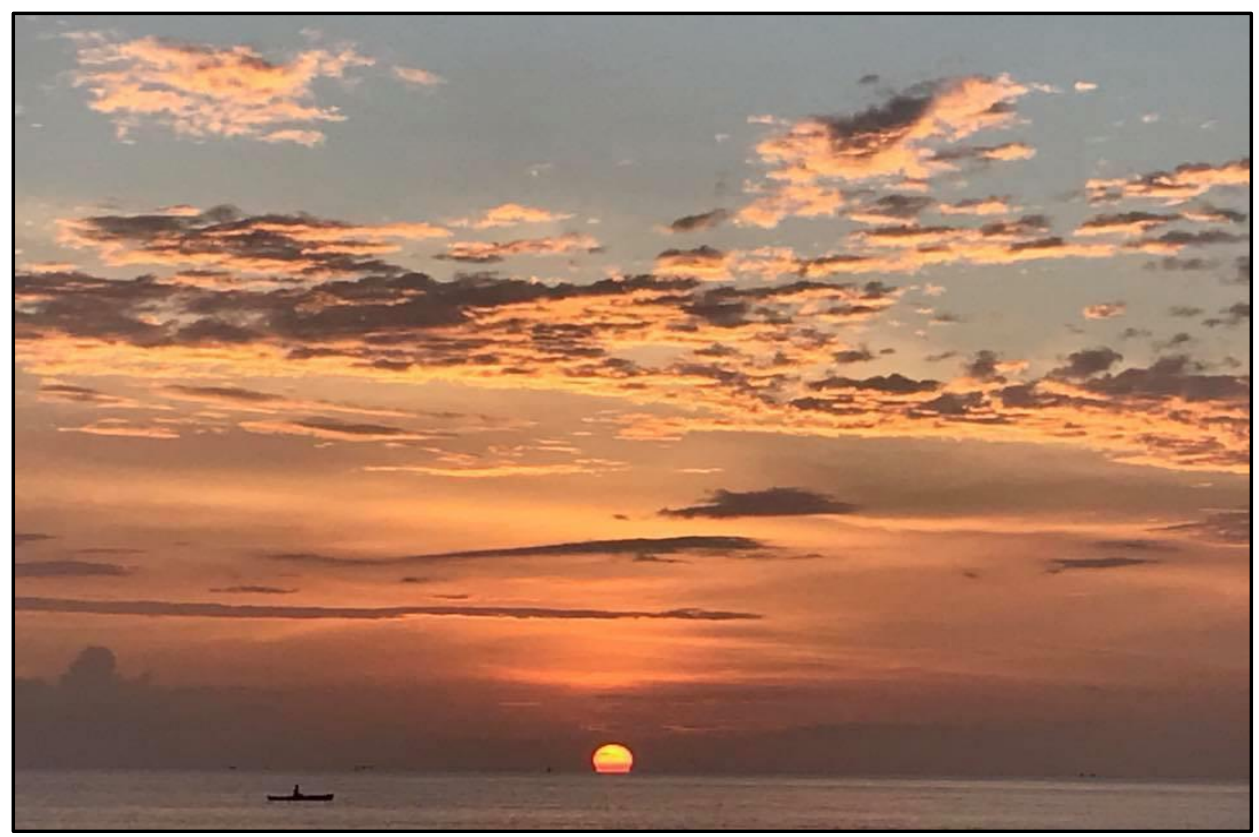

Gambar 4. Menyaksikan Keindahan Sunset di Pantai Molotabu

Peringatan hari Asyura dilaksanakan oleh masyarakat Molotabu sebagai bagian dari adat istiadat memperingati hari-hari besar Islam sangat menarik untuk disaksikan. Masyarakat melalukan zikir dan doa semalam suntuk dan dilanjutkan besok harinya melaksanakan adat mandi bersama di Pantai Molotabu. Kegiatan ini merupakan kearifan local masyarakat Molotabu yang dilaksanakan setiap peringatan hari Asyura. Peringatan hari Asyura ditunjukkan pada Gambar 5.

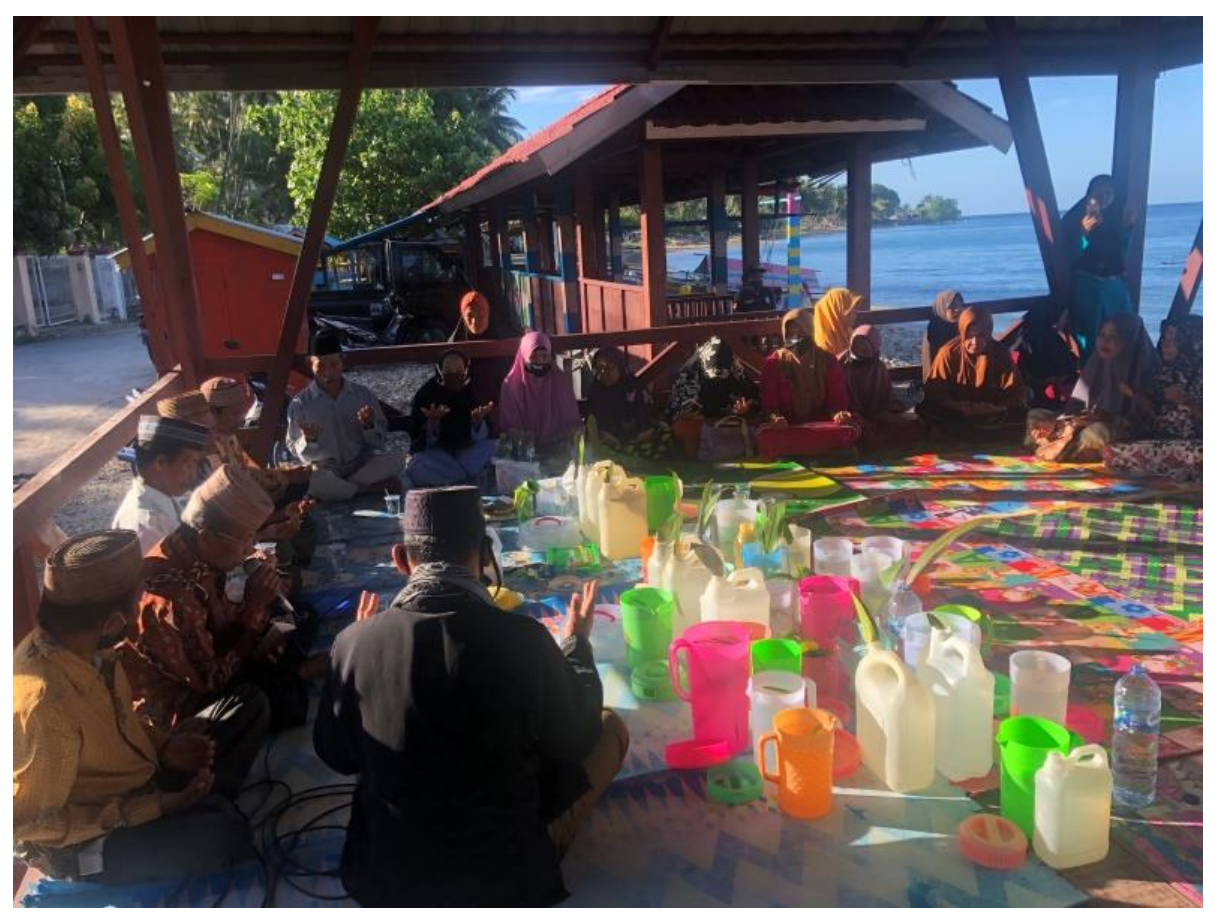

Gambar 5. Peringatan Hari Asyura di Pantai Molotabu

Konsep ekowisata menitikberatkan pada pemanfaatan sumberdaya lokal. Hal ini terlihat dengan semakin berkembangnya obyek wisata Pantai Molotabu yang ditandai dengan banyaknya kunjungan wisatawan sehingga menghasilkan membawa dampak positif. Dampak positifnya jelas ekonomi masyarakat Desa Molotabu sebagai pelaku wisata akan meningkat sehingga tujuan utama pengembangan ekowisata dapat tercapai. 


\section{KESIMPULAN}

Berdasarkan hasil analisis parameter fisik pantai yakni vegetasi, kebersihan lingkungan, material pantai dan kecerahanan air Pantai Molotabu memiliki potensi tinggi. Hasil yang sama juga diperoleh untuk pengukuran parameter fisik meliputi jarak, sarana prasarana aksesibilitas dan daya tarik kawasan ekowisata Pantai Molotabu. Potensi tinggi ekowisata diperoleh juga dari kriteria berdasarkan parameter kelembagaan, sosial budaya, ekonomi dan lingkungan. Tingginya potensi ekowisata Pantai Molotabu karena kawasan pantai ini memiliki ciri pantai memanjang yang terbentuk secara alamiah. Selain itu, peran serta masyarakat secara swadaya dengan membuat bangunan fasilitas tempat wisata menjadi nilai tambah untuk pengembangan ekowisata Pantai Molotabu. Keindahan alam yang utuh, kekhasan budaya, dan sejarah dimanfatakan masyarakat tanpa merusak isinya. Adanya potensi pemandangan alam menikmati sunrise dan sunset, keindahan laut untuk kegiatan snorkeling dan diving, kerajinan, kesenian daerah (wisata budaya), peringatan hari Asyura serta kuliner menjadi daya tarik. Pengembangan potensi ekowisata Pantai Molotabu harus terus berjalan guna memberikan keuntungan secara ekonomi sehingga dapat meningkatkan pendapatan masyarakat.

\section{DAFTAR PUSTAKA}

Eraku, S, S., Permana, A, P., dan Hulukati, E., 2017. Potensi sumber daya alam fosil kayu di daerah Gorontalo/local wood fossil potential in Gorontalo. Jurnal Pengelolaan Sumber Daya Alam dan Lingkungan, Vol 7(2) : 172-177. DOI: https://doi.org/10.29244/jps1.7.2.172-177.

Eraku, S, S., and Permana, A, P., 2020. Erosion Hazard Analysis in The Limboto Lake Catchement Area, Gorontalo Province, Indonesia. News of the National Academy of Sciences of the Republic of Kazakhstan, Series of Geology and Technical Sciences. Vol. 3 (441): 110-116. DOI: https://doi.org/10.32014/2020.2518-170X.61.

Ghorbani, A., Raufirad, V., Rafiaani, P., and Azadi, H., 2015. Ecotourism sustainable development strategies using SWOT and QSPM model: A case study of Kaji Namakzar Wetland, South Khorasan Province, Iran. Tourism Management Perspectives, 16 : 290-297. https://doi.org/10.1016/j.tmp.2015.09.005.

Haryanto, J, T., 2014. Model Pengembangan Ekowisata Dalam Mendukung Kemandirian Ekonomi Daerah Studi Kasus Provinsi DIY. KAWISTARA. Vol. 4(3) : 225-330.

Kementerian Pariwisata dan Ekonomi Kreatif., 2020. Dokumen Rencana Strategis Kementerian Pariwisata dan Ekonomi Kreatif/Badan Pariwisata dan Ekonomi Kreatif Tahun 2020 2024. Jakarta.

Liu, J., Qu, H., Huang, D., Chen, G., Yue, X., Zhao, X., and Liang, Z., 2014. The role of social capital in encouraging residents' pro-environmental behaviors in community-based ecotourism. Tourism Management, $41 \quad$ : 190-201. https://doi.org/10.1016/j.tourman.2013.08.016.

Motlagh, E. Y., Hajjarian, M., Zadeh, O. H., and Alijanpour, A., 2020. The difference of expert opinion on the forest-based ecotourism development in developed countries and Iran. Land Use Policy, 94 : 104549. https://doi.org/10.1016/j.landusepol.2020.104549.

Nyaupane, G, P., and Poudel, S., 2011. Linkages among biodiversity, livelihood, and tourism. Annals of Tourism Research, 38(4) : 1344-1366. https://doi.org/10.1016/j.annals.2011.03.006.

Peraturan Menteri Dalam Negeri Nomor 33 Tahun 2009 Tentang Pedoman Pengembangan Ekowisata di Daerah.

Permana, A. P., dan Eraku, S. S., 2017. Analisis stratigrafi Daerah Tanjung Kramat Kecamatan Hulonthalangi Kota Gorontalo. Jurnal Geomine. Vol. 5 (1): 1-6. DOI: https://doi.org/10.33536/jg.v5i1.

Permana, A.P., 2018. Potensi Batugamping Terumbu Gorontalo Sebagai Bahan Galian Industri Berdasarkan Analisis Geokimia XRF. Enviroscienteae, Vol. 14 (3) : 174-179. DOI: 10.20527/es.v14i3.5688

Permana, A, P., Pramumijoyo, S., and Akmaluddin., 2019a. Uplift Rate of Gorontalo Limestone (Indonesia) Based on Biostratigraphy Analysis. News of the National Academy of Sciences 
Eraku, S. S., dkk., 2020 Jurnal Sains Informasi Geografi [J SIG], 3(2):100-107, ISSN 2614-

1671

of the Republic of Kazakhstan, Series of Geology and Technical Sciences. Vol. 6 (438): 6-11. DOI: https://doi.org/10.32014/2019.2518-170X.150.

Permana, A, P., Pramumijoyo, S., and Akmaluddin., 2019b. Analysis of Microfacies and Depositional of Limestone in Yosonegoro Area, Gorontalo Province, Indonesia. Bulletin of the Iraq Natural History Museum. Vol. 15 (4): 443-454. DOI: https://doi.org/10.26842/binhm.7.2019.15.4.0443.

Permana, A, P., Pramumijoyo, S., and Akmaluddin. 2020., Paleobathymetry Analysis of Limestone in Bongomeme Region Based on Content of Benthic Foraminifera Fossil, Gorontalo District, Indonesia. Bulletin of the Iraq Natural History Museum. Vol. 16 (1): 114. DOI: https://doi.org/10.26842/binhm.7.2020.16.1.0001.

Pramudya, E., 2008. Evaluasi Potensi Obyek Wisata Aktual Di Kabupaten Agam Sumatera Barat Untuk Perencanaan Program Pengembangan: Bogor : Sekolah Pascasarjana Institut Pertanian Bogor.

Qian, C., Sasaki, N., Shivakoti, G., and Zhang, Y., 2016. Effective governance in tourism development - An analysis of local perception in the Huangshan mountain area. Tourism Management Perspectives. 20 : 112-123.

Vitasurya, V, R., 2015. Local Wisdom for Sustainable Development of Rural Tourism, Case on Kalibiru and Lopati Village, Province of Daerah Istimewa Yogyakarta. Social and Behavioral Sciences. 216 : 97-108.

Walpole, R, E., 1982. Introduction of Statistics. 3rd Edition, Macmillan Publishing Company, Inc., New York, 247-304.

WWF (World Wildlife Fund)., 2009. Prinsip dan Kriteria Ekowisata Berbasis Masyarakat. Departemen Kebudayaan dan Pariwisata dan WWF, Indonesia.

Zambrano, A. M. A., Broadbent, E. N., and Durham, W. H., 2010. Social and environmental effects of ecotourism in the Osa Peninsula of Costa Rica: The Lapa Rios case. Journal of Ecotourism, Vol. 9(1) : 62-83. https://doi.org/10.1080/14724040902953076. 